\title{
JNVESTGAATONN
}

\section{Lipid damage development in anchovy (Engraulis encrasicholus) muscle during storage under refrigerated conditions}

\section{By Nour-Eddine Chaouqy ${ }^{1}$, José M. Gallardo ${ }^{2}$, Abdelhaq El Marrakchi ${ }^{3}$ and Santiago P. Aubourg ${ }^{2,}{ }^{*}$}

\author{
${ }^{1}$ Laboratoire Régional d'Analyses et de Recherches Vétérinaires, Agadir (Morocco). \\ ${ }^{2}$ Instituto de Investigaciones Marinas (CSIC), Vigo (Galicia, Spain). \\ ${ }^{3}$ Departement d'Hygiène et Industrie des Denrées Alimentaires d'Origine Animale. Institut \\ Agronomique et Vétérinaire Hassan II. Rabat (Morocco). \\ * Corresponding author: Fax: +34 986 292762; e-mail: saubourg@iim.csic.es
}

\section{RESUMEN}

Desarrollo de la alteración lipídica en músculo de anchoa (Engraulis encrasicholus) durante su conservación en refrigeración.

Se estudió la evolución de la alteración lipídica en músculo de anchoa (Engraulis encrasicholus) bajo distintas condiciones de conservación. Anchoa fresca fue tratada con sal (condición S), hielo (condición I) y con hielo-sal (condición IS) y almacenada en cámara refrigerada $\left(4^{\circ} \mathrm{C}\right)$, procediéndose a su análisis los días 0, 2, 4, 6, 8, 10 y 12 de almacenamiento. Se observó un fuerte desarrollo de hidrólisis lipídica en todas las condiciones de conservación, aunque la presencia de sal significó una inhibición parcial $(p<0.05)$ de dicha vía de alteración (condiciones S e IS). Asimismo, la oxidación primaria reflejó valores menores $(p<0.05)$ para pescado conservado en la condición I. Este resultado fue corroborado por una menor formación de compuestos de interacción entre lípidos oxidados y proteínas (menor desarrollo de fluorescencia y pardeamiento). Se concluye un mayor desarrollo de la oxidación lipídica como resultado de la presencia de sal (condiciones S e IS).

PALABRAS CLAVE: Anchoa - Calidad - Hidrólisis lipídica - Hielo - Oxidación lipídica - Sal.

\section{SUMMARY}

Lipid damage during anchovy refrigerated storage.

The evolution of lipid damage in anchovy (Engraulis encrasicholus) muscle was studied under different storage conditions. Fresh anchovy was exposed to salt (S condition), ice (I condition) and salt-ice (IS condition), kept in a refrigerated room $\left(4^{\circ} \mathrm{C}\right)$, and analyzed at days $0,2,4,6,8$, 10 and 12 of storage. A strong hydrolysis development could be assessed for all storage conditions, although a partial hydrolysis inhibition $(p<0.05)$ could be attained as a result of the presence of salt (S and IS conditions). In contrast, a lower $(p<0.05)$ primary lipid oxidation compound formation could be observed for individuals kept under I conditions. This conclusion was confirmed by the interaction compound formation study (fluorescence and browning developments) between oxidized lipids and protein-type molecules. Accordingly, a higher lipid oxidation was inferred as a result of $\mathrm{NaCl}$ addition to fish (S and IS conditions).
KEY-WORDS: Anchovy - Ice - Lipid hydrolysis - Lipid oxidation - Quality - Salt.

\section{INTRODUCTION}

Marine products constitute a highly perishable food group (Pigott and Tucker, 1990; Ashie et al., 1996). Deterioration of fish species begins immediately upon capture, and the degree to which it continues depends directly on storage conditions. Among the different on-board treatments, chilling storage has been the most commonly employed for fish to be commercialized as fresh or further processed (Whittle et al., 1990; Madrid et al., 1994).

Different mechanisms have been found responsible for fish deterioration during chilled storage (Olafsdóttir et al., 1997; Howgate, 2006). Thus, marine lipids are comprized of highly unsaturated fatty acids that are known to be highly prone to oxidation (Hsieh and Kinsella, 1989; Harris and Tall, 1994). During the chilled storage of fish, lipids have been reported to undergo hydrolysis and oxidation reactions that can lead to important losses in sensory and nutritional qualities with an important impact on its commercial value (Undeland et al., 1999; Chaijan et al., 2006).

Anchovy (Engraulis encrasicholus) is a small pelagic fish of great economic importance in many countries (FAO, 2006a). Part of the catch is directly consumed as fresh or is processed for fish meal and oil, while the greatest portion is destined for the ripening process. Anchovy ripening leads to the manufacturing of a high quality canned product that is responsible for a large commercial trade in countries like Morocco and Spain (FAO, 2006b). Previous research concerning anchovy changes before the ripening process accounts for chilling (Careche et al., 2002; Pons-Sánchez-Cascado et al., 2006), frozen (Karaçam and Boran, 1996; Rossano et al., 2006) and temperate (Martínez and Gildberg, 1988; Visciano et al., 2007) storage conditions. In such studies, volatile and biogenic 
amine formation, microbiological development and sensory quality loss have been widely measured, while lipid damage studies have been scarce.

For small pelagic fish, it is a frequent practice in certain countries to add common salt to the ice during the storage steps previous to consumption or further processing (Slabyj and True, 1978; Huidobro et al., 1990; Toledo-Flores and Zall, 1994). The purpose of the salt addition is to improve texture, prolong preservation and provide a more valuable starting material for further processing. However, owing to the lipid pro-oxidant effect reported for $\mathrm{NaCl}$ presence (Maruf et al., 1990; Aubourg and Ugliano, 2002), some detrimental effects on lipid composition may be encountered, especially in cases where a fatty fish is concerned. In the present work, the lipid damage in anchovy muscle is studied during its refrigerated storage. Special emphasis is placed on the effect of $\mathrm{NaCl}$ presence on lipid hydrolysis and oxidation development.

\section{MATERIALS AND METHODS}

\subsection{Raw material, processing, sampling, and chemicals}

Fresh anchovies (Engraulis encrasicholus) were caught off the coast of Agadir (Morocco) and transported on ice to laboratory 6 hours after being caught. Part of the fish were taken as initial raw fish (day 0 ), while the remaining individuals were divided into three batches, each of them exposed to the following conditions: a) Salt addition ( $5 \% \mathrm{w} / \mathrm{w}$, salt/fish) (S condition); b) Ice condition ( $25 \% \mathrm{w} / \mathrm{w}$, ice/fish) (I condition); c) Salt addition (5\% w/w, salt/fish) and ice condition ( $25 \% \mathrm{w} / \mathrm{w}$, ice/fish) (IS condition). All fish batches were then placed in a refrigerated room at $4^{\circ} \mathrm{C}$.

Throughout the experiment, the temperature of fish kept under the different conditions was measured. Individual temperature at $\mathrm{S}$ condition was $4^{\circ} \mathrm{C}$, while temperature of their counterparts at IS and I conditions was in the range $0-1^{\circ} \mathrm{C}$. The temperature of the salt-ice mixture was between $-1^{\circ} \mathrm{C}$ and $0^{\circ} \mathrm{C}$.

The fish were taken for analysis at days $0,2,4$, $6,8,10$ and 12 of storage. In each sample, analyses were carried out on the homogenized white muscle of six individual fish. For initial fish and for each refrigerated condition, three different groups $(n=3)$ were considered and studied separately to achieve the statistical study.

Chemicals employed along the present work (solvents, reagents) were reagent grade (E. Merck; Darmstadt, Germany); $\mathrm{NaCl}$ employed included a maximum content of iron and copper of $0.0001 \%$ and $0.0002 \%$, respectively.

\section{2. $\mathrm{NaCl}$ content assessment}

$\mathrm{NaCl}$ content was determined by the Charpentier and Volhard (AOAC, 1980) method and expressed as $\mathrm{g} \mathrm{NaCl} / 100 \mathrm{~g}$ muscle.

\subsection{Lipid analysis}

Lipids were extracted by the method of Bligh and Dyer (1959).

Free fatty acid (FFA) content was determined on the Bligh and Dyer (1959) extract by the Lowry and Tinsley (1976) method based on complex formation with cupric acetate-pyridine. Results are expressed as g FFA/ $100 \mathrm{~g}$ lipid.

Peroxide value (PV) expressed as meq active oxygen/ $\mathrm{kg}$ lipid was determined by the ferric thiocyanate method (Chapman and McKay, 1949) on the Bligh and Dyer (1959) extract.

The thiobarbituric acid index (TBA-i) was determined on a $5 \%$ trichloracetic acid extract according to the Vyncke (1970) method and expressed as $\mathrm{mg}$ malondialdehyde/ $\mathrm{kg}$ fish muscle.

Lipid extracts were converted into fatty acid methyl esters and analyzed by gas chromatography (Medina et al., 1994). The polyene index (PI) in the different samples was calculated as the following

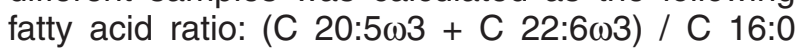
(Lubis and Buckle, 1990).

\subsection{Interaction compound formation}

The formation of protein-oxidized lipid interaction compounds was measured by the fluorescence formation and browning detection.

Fluorescence formation (Perkin-Elmer LS 3B) at $327 / 415 \mathrm{~nm}$ and $393 / 463 \mathrm{~nm}$ was studied as described previously (Aubourg and Medina, 1999; Aubourg, 2001). The relative fluorescence (RF) was calculated as follows: $R F=F / F_{\text {st }}$, where $F$ is the fluorescence measured at each excitation/emission pair, and $\mathrm{F}_{\mathrm{st}}$ is the fluorescence intensity of a quinine sulphate solution $\left(1 \mathrm{mg} / \mathrm{ml}\right.$ in $\left.0.05 \mathrm{M} \mathrm{H}_{2} \mathrm{SO}_{4}\right)$ at the corresponding wavelength. The fluorescence ratio (FR) was measured in the chloroform-methanol lipid extract, according to the following calculation: $F R=$ $\mathrm{RF}_{393 / 463 \mathrm{~nm}} / \mathrm{RF}_{327 / 415 \mathrm{~nm} \text {. }}$

Brown color formation (BCF) was determined at $400 \mathrm{~nm}$ and $450 \mathrm{~nm}$ in the chloroform-methanol lipid extract according to Hassan et al. (1999). Results are expressed as the browning ratio between both wavelength assessments $\left(\mathrm{BCF}_{450} / \mathrm{BCF}_{400}\right)$.

\subsection{Statistical analyses}

Data from the different quality measurements were subjected to the ANOVA one-way method $(p<0.05)$ (Statsoft, 1994); comparison of means was performed using a least-squares difference (LSD) method.

\section{RESULTS AND DISCUSSION}

\section{1. $\mathrm{NaCl}$ content}

The $\mathrm{NaCl}$ content of anchovy muscle is expressed in Figure 1. The presence of salt during the refrigeration storage ( $S$ and IS conditions) has 


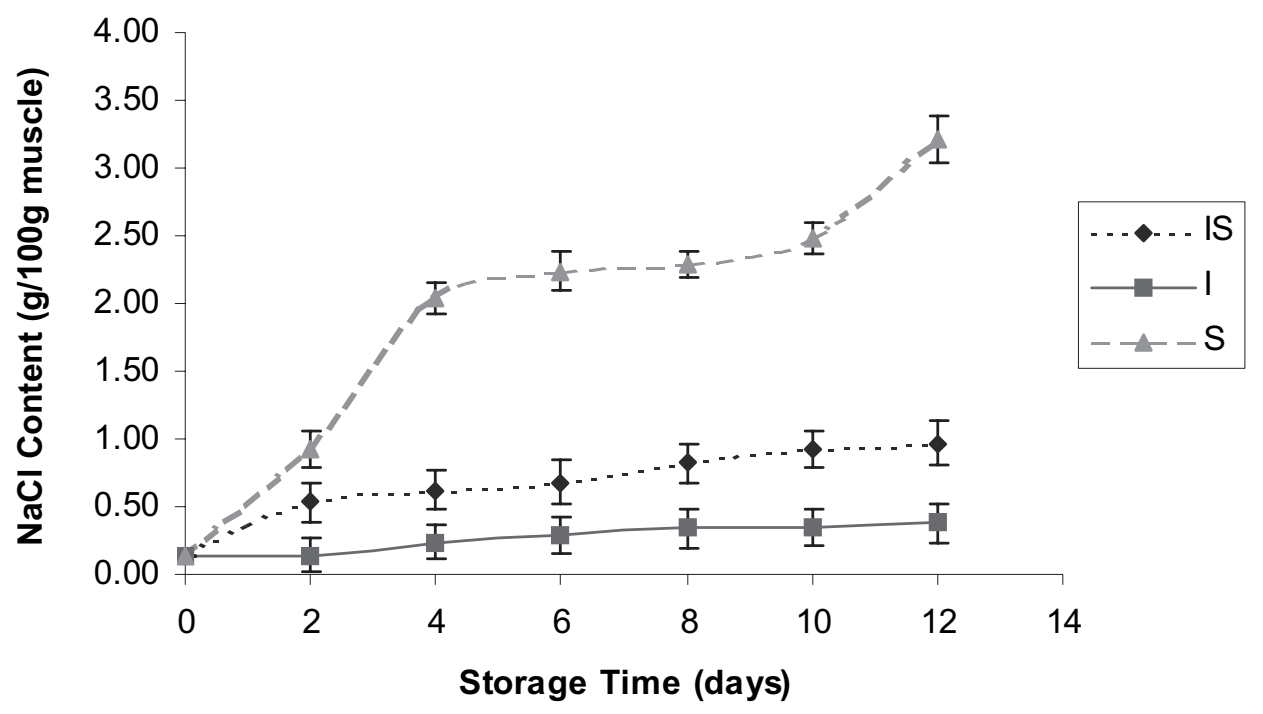

Figure 1

$\mathrm{NaCl}$ content* in anchovy muscle stored under different conditions ${ }^{* *}$

*Mean values of three independent determinations $(n=3)$. Standard deviations are indicated by brackets. ${ }^{*}$ Storage conditions: S (salt), I (ice), and IS (ice and salt).

led to a marked increase $(\mathrm{p}<0.05)$ in $\mathrm{NaCl}$ content with storage time in fish white muscle. Thus, comparison among fish individuals corresponding to the three storage conditions showed a significant $(p<0.05)$ increase according to the following sequence: I < IS < S. Differences could easily be observed from day 2.

Fish stored under $\mathrm{S}$ condition $\left(4^{\circ} \mathrm{C}\right)$ provided a sharp $\mathrm{NaCl}$ content increase that can be explained as a $\mathrm{NaCl}$ diffusion into the white muscle during storage (Losada et al., 2004; Huidobro et al., 1990). However, in the presence of ice (IS condition), this $\mathrm{NaCl}$ diffusion was found to be slower $(p<0.05)$, as a result of the lower storage temperature that leads to a lower availability of $\mathrm{NaCl}$ to diffuse into the fish body.

$\mathrm{NaCl}$ values attained by individuals kept under IS conditions can be considered higher than those obtained for fish kept under slurry ice conditions (Losada et al., 2004) and in the same range as those reported for fish stored under refrigerated sea water (RSW) (Smith et al., 1980). For fish treated under S conditions, $\mathrm{NaCl}$ values actually obtained are higher than those reported for RSW (Smith et al., 1980) conditions but lower than the ones obtained in salted fish (Thorarinsdóttir et al., 2002) or in cases where salting is followed by smoking (Jittinandana et al., 2002).

\subsection{Lipid hydrolysis}

A gradual increase $(p<0.05)$ in FFA formation was observed throughout the storage time for fish kept under the three conditions (Figure 2). Comparison among the three treatments provided a higher $(p<0.05)$ FFA formation in samples where no $\mathrm{NaCl}$ addition was included (I condition), while no differences $(p>0.05)$ could be observed between S and IS conditions. An inhibitory effect of salt on hydrolysis development could be inferred, effective even if ice was also present (IS condition). Such inhibitory effect on FFA formation during fish processing has already been reported for salt presence (Takiguchi, 1989; Aubourg and Ugliano, 2002). In addition, a partial inhibition effect of brine freezing (Aubourg and Gallardo, 2005) and of previous treatment with other kinds of salts $(\mathrm{NaOCl}$ and $\mathrm{NaF}$ ) (Hwang and Regenstein, 1995) has also been inferred.

In previous research (Shewfelt, 1981; Whittle et al., 1990; Aubourg and Medina, 1999), free fatty acid formation has shown to increase with storage temperature under frozen and refrigerated conditions as a result of endogenous enzyme activity and microbial development. In the present case, in spite of the lower temperature for individuals kept under I conditions $\left(0-1^{\circ} \mathrm{C}\right)$, those stored under $\mathrm{S}$ conditions $\left(4^{\circ} \mathrm{C}\right)$ showed a lower hydrolysis development as a result of the $\mathrm{NaCl}$ presence.

While the formation of FFA itself does not lead to nutritional losses, its assessment is deemed important when considering the development of rancidity. Thus, a pro-oxidant effect of FFA on lipid matter has been proposed and explained on the basis of a catalytic effect of the carboxyl group on the formation of free radicals by the decomposition of hydroperoxides (Yoshida et al., 1992; Aubourg, 2001). In addition, FFA have shown to interact with proteins leading to texture deterioration (Mackie, 1993).

\subsection{Lipid oxidation}

For fish kept under all kinds of conditions checked, an important peroxide formation $(p<0.05)$ could be outlined after 6 days, when relatively high 


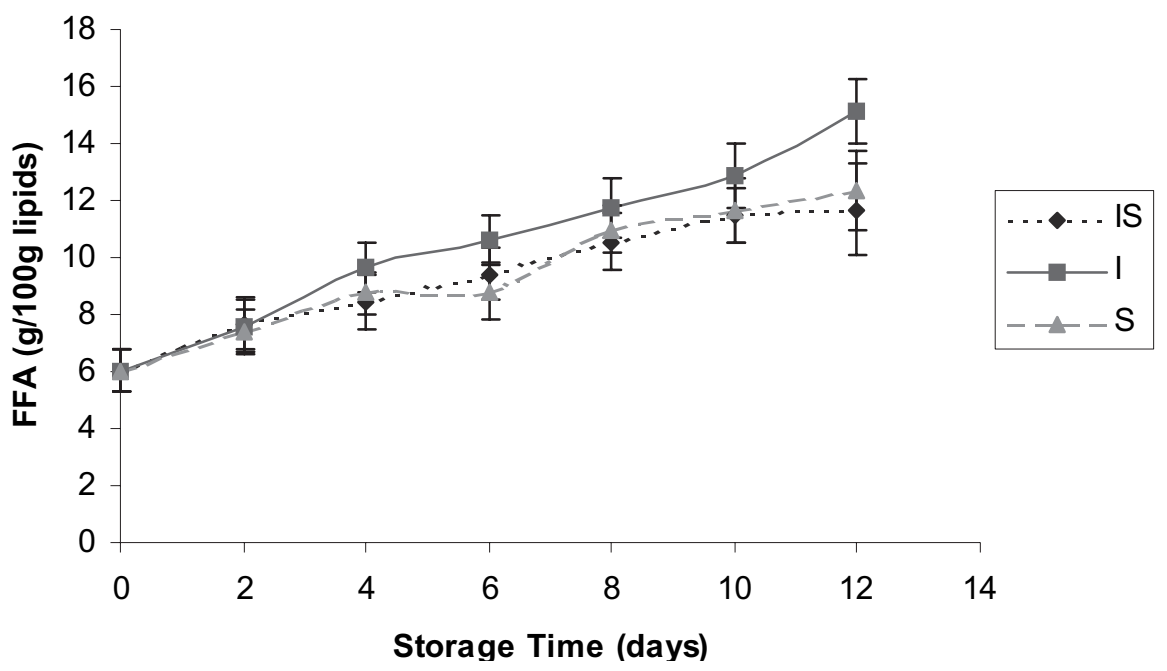

Figure 2

Free fatty acid content (FFA) in anchovy muscle stored under different conditions ${ }^{* *}$

${ }^{*}$ Mean values of three independent determinations $(n=3)$. Standard deviations are indicated by brackets. ${ }^{* *}$ Storage conditions as expressed in Figure 1.

values (PV > 14.0) were obtained in all cases; after this time, individuals kept under IS and I conditions showed a marked PV decrease until the end of the study. In the case of $S$ conditions, a gradual peroxide formation $(p<0.05)$ was still observed until day 10. At the end of the experiment (day 12), a peroxide breakdown $(p<0.05)$ was evident for fish material kept under the three treatments.

Comparison among storage conditions showed some PV differences at days 4, 8 and 10, where it can be concluded that individuals kept under ice treatment (I condition) provided a lower value than their counterparts kept under S and IS conditions where salt is included.

The thiobarbituric acid reactive substances (TBARS) formation showed a significant increase $(p<0.05)$ with storage time until day 4 for fish muscle kept under all kinds of conditions. After this sampling time, no differences $(p>0.05)$ were observed as a result of refrigeration time. The general peroxide breakdown observed at day 12 did not lead to an increase in TBARS formation. Comparison among treatments showed a lower TBARS formation for fish individuals kept under I treatment at day 2 and a higher formation for those stored under $\mathrm{S}$ conditions at day 10.

Although a definite effect on secondary lipid oxidation formation (TBA-i) could not be observed, present results have shown a marked effect of the $\mathrm{NaCl}$ content of fish muscle on the primary oxidation formation (PV). These results agree with previous research carried out on fatty fish species such as sardine (Takiguchi, 1989), mackerel (Maruf et al., 1990) and horse mackerel (Aubourg and Ugliano, 2002). Indeed, brine freezing treatment has also been shown to lead to a higher lipid oxidation development as a result of an $\mathrm{NaCl}$ content increase in mackerel and horse mackerel muscle (Aubourg and Gallardo, 2005). Sodium chloride has been reported to act as a pro-oxidant by enhancement of the pro-oxidant effect of chelatable iron ions (Kanner et al., 1991) widely present in fish muscle, especially in the dark one (Ackman, 1989).

The pro-oxidant effect of the $\mathrm{NaCl}$ presence was reinforced by a lower storage temperature for individuals under $\mathrm{S}$ conditions $\left(4^{\circ} \mathrm{C}\right)$ when compared to the temperature of their counterparts kept under IS and I conditions $\left(0-1^{\circ} \mathrm{C}\right)$. It is well known that under frozen and refrigeration conditions, a temperature increase would lead to an increased lipid oxidation development as a result of an enzymatic and non-enzymatic lipid oxidation pathway (Slabyj and True, 1978; Smith et al., 1980; Aubourg and Medina, 1999).

\subsection{Fatty acid analysis and polyene index}

Fatty acid analysis of the starting fish material led to the following proportions (\%): 2.2 (C 14:0), 18.3 (C 16:0), 2.3 (C 16:1 $\omega 5$ ), 4.0 (C 18:0), 5.3

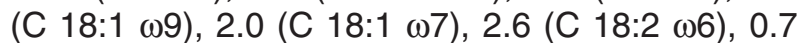

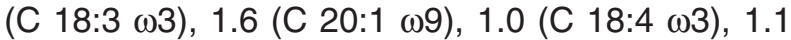

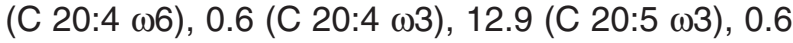

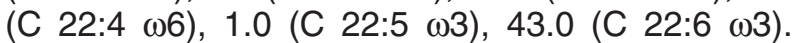
Thus, the most abundant fatty acid was $C 22: 6 \omega 3$ (docosahexaenoic acid, DHA), followed by C 16:0 (palmitic acid) and C 20:5 13 (eicosapentaenoic acid, EPA). Accordingly, profitable $\omega 3$ (round $59 \%$ ) and $\omega 3 / \omega 6$ ratio (round 13 ) values were obtained, in agreement with previous reports related to the recommended values for the human diet of the western population (Simopoulos, 1994).

Damage to polyunsaturated fatty acids during the present storage conditions was measured by the $\mathrm{PI}$ assessment. This index did not provide differences among treatments at any of the storage times. However, all kinds of fish samples showed a PI decrease $(p<0.05)$ at day 12 , according to the remarkable primary and secondary lipid oxidation compound development. 


\subsection{Interaction compound formation}

Fluorescence analysis provided an increasing value $(p<0.05)$ with storage time for all kinds of samples. This result agrees with the important primary and secondary lipid oxidation compound formation. Comparison among storage conditions provided lower values for those individuals that had been kept under I conditions than for their counterparts kept under S conditions for the 6-12 day period. At the same time, IS conditions led to lower values than $S$ conditions in the 8-12 day period. Differences between IS and I conditions could only be observed at the end of the experiment, where the salt presence led to a higher fluorescence formation.

Browning assessment in anchovy muscle again provided increasing $(p<0.05)$ values throughout the storage time for all the conditions tested, according to an increasing lipid oxidation formation.
No differences among treatments could be outlined in the 0-8 day period. After that storage time, individuals from the $S$ condition showed a higher browning development than their counterparts stored under IS and I conditions. No differences could be assessed between IS and I treatments.

Present results concerning the interaction compound (or tertiary lipid oxidation compounds) study have shown an important lipid oxidation formation that can be attributed to the $\mathrm{NaCl}$ presence in fish muscle. Such fluorescence and browning development produced in cases where an increased $\mathrm{NaCl}$ content is observed agrees with previous research under different processing conditions (Maruf et al., 1990; Lubis and Buckle, 1990; Aubourg and Ugliano, 2002; Aubourg and Gallardo, 2005). In the meantime, a temperature increase has been reported to lead to a higher interaction compound formation (Pokorný, 1981;

Table 1

Assessment ${ }^{\star}$ of peroxide value, thiobarbituric acid index and polyene index in anchovy muscle stored under different conditions ${ }^{\star *}$

\begin{tabular}{crrrrrrrrr}
\hline \multirow{2}{*}{$\begin{array}{c}\text { Storage Time } \\
\text { (days) }\end{array}$} & \multicolumn{3}{c}{ Peroxide Value } & \multicolumn{3}{c}{ Thiobarbituric Acid Index } & \multicolumn{3}{c}{ Polyene Index } \\
\cline { 2 - 12 } & \multicolumn{1}{c}{ IS } & \multicolumn{1}{c}{ I } & \multicolumn{1}{c}{ S } & \multicolumn{1}{c}{ IS } & \multicolumn{1}{c}{ I } & S & IS & I & S \\
\hline 0 & & 3.1 & & & 0.14 & & & 3.05 & \\
2 & $6.3 \mathrm{a}$ & $7.2 \mathrm{a}$ & $10.4 \mathrm{~b}$ & $0.98 \mathrm{~b}$ & $0.68 \mathrm{a}$ & $0.95 \mathrm{~b}$ & 2.82 & 3.07 & 3.06 \\
4 & $11.2 \mathrm{~b}$ & $7.7 \mathrm{a}$ & $10.1 \mathrm{~b}$ & 1.21 & 1.14 & 1.28 & 3.00 & 3.04 & 2.89 \\
6 & $19.4 \mathrm{~b}$ & $14.5 \mathrm{a}$ & $14.7 \mathrm{a}$ & 1.28 & 1.29 & 1.39 & 2.95 & 3.03 & 2.87 \\
8 & $18.5 \mathrm{~b}$ & $13.8 \mathrm{a}$ & $14.8 \mathrm{~b}$ & 1.32 & 1.29 & 1.34 & 2.83 & 2.93 & 3.03 \\
10 & $14.4 \mathrm{~b}$ & $10.7 \mathrm{a}$ & $18.9 \mathrm{~b}$ & $1.30 \mathrm{a}$ & $1.34 \mathrm{a}$ & $1.58 \mathrm{~b}$ & 3.03 & 3.12 & 2.94 \\
12 & 5.3 & 7.8 & 6.6 & 1.23 & 1.34 & 1.28 & 2.75 & 2.63 & 2.70 \\
\hline
\end{tabular}

* Mean values of three independent determinations $(n=3)$. For each quality index and at each storage time, mean values followed by different letters $(a, b)$ indicate significant $(p<0.05)$ differences among storage conditions.

** Storage conditions: IS (ice and salt), I (ice) and S (salt).

Table 2

Fluorescence and browning ratios assessment* in anchovy muscle stored under different conditions ${ }^{\star *}$

\begin{tabular}{ccccccc}
\hline \multirow{2}{*}{$\begin{array}{c}\text { Storage Time } \\
\text { (days) }\end{array}$} & \multicolumn{3}{c}{ Fluorescence Ratio } & \multicolumn{3}{c}{ Browning Ratio } \\
\cline { 2 - 7 } & IS & I & S & IS & I & S \\
\hline 0 & & 0.96 & & & 0.54 & \\
\hline 2 & 1.28 & 1.22 & 1.23 & 0.54 & 0.60 & 0.55 \\
4 & 1.27 & 1.42 & 1.41 & 0.55 & 0.61 & 0.54 \\
6 & $1.68 \mathrm{ab}$ & $1.47 \mathrm{a}$ & $1.86 \mathrm{~b}$ & 0.68 & 0.69 & 0.73 \\
8 & $1.95 \mathrm{a}$ & $1.75 \mathrm{a}$ & $2.74 \mathrm{~b}$ & 0.91 & 0.84 & 1.05 \\
10 & $2.06 \mathrm{a}$ & $1.85 \mathrm{a}$ & $3.83 \mathrm{~b}$ & $0.99 \mathrm{a}$ & $0.89 \mathrm{a}$ & $1.48 \mathrm{~b}$ \\
12 & $2.33 \mathrm{~b}$ & $2.09 \mathrm{a}$ & $5.71 \mathrm{c}$ & $1.13 \mathrm{a}$ & $0.95 \mathrm{a}$ & $2.29 \mathrm{~b}$ \\
\hline
\end{tabular}

\footnotetext{
* Mean values of three independent determinations $(n=3)$. For each quality index and at each storage time, mean values followed by different letters $(a, b, c)$ indicate significant $(p<0.05)$ differences among storage conditions.

** Storage conditions as expressed in Table 1.
} 
Aubourg and Medina, 1999). According to the present results, the higher storage temperature for S conditions than for I and IS conditions would also favor a greater interaction compound formation.

\section{CONCLUSIONS}

For all kinds of storage conditions checked in the present study, a remarkable lipid hydrolysis and oxidation development was assessed in anchovy muscle lipids.

Chilling (I conditions) has shown to be a better storage technology than salt (S conditions) and icesalted (IS conditions) treatments in order to partially inhibit lipid oxidation development. This result can be explained on the basis of a pro-oxidant effect of the $\mathrm{NaCl}$ presence in muscle ( $\mathrm{S}$ and IS conditions) and as a result of employing a higher holding temperature in the $\mathrm{S}$ conditions $\left(4^{\circ} \mathrm{C}\right)$. According to the $\mathrm{NaCl}$ content in muscle and to the storage temperature, lipid oxidation development was found lower in individuals kept under IS conditions than in their counterparts stored under S conditions.

Related to lipid hydrolysis, an inhibitory effect on FFA formation could be inferred for the $\mathrm{NaCl}$ presence in anchovy muscle. Thus, the addition of salt to ice (IS conditions) showed to be a better holding strategy than chilling (I condition) in order to partially prevent the lipid hydrolysis development.

\section{ACKNOWLEDGEMENTS}

The authors thank Dr. Touti Jamal chief of the L.R.A.R.V. Agadir for his helpful collaboration, Mr. Marcos Trigo and Mrs. Janet Ares for technical assistance and the financial support provided by a Cooperation Program Morocco-Spain (CNCPRST-CSIC; Project 2000 MA 0033).

\section{REFERENCES}

Ackman R. 1989. Fatty acids in Ackman R (Ed.) Marine Biogenic Lipids, Fats and Oils, Vol. 1, 103-137. CRC Press, Boca Raton, FI, USA.

AOAC. 1980. Official methods of analysis of the Association of Analytical Chemistry, $13^{\text {th }}$ ed., p. 289. Association of Official Analytical Chemists, Washington DC, USA.

Ashie I, Smith J, Simpson B. 1996. Spoilage and shelf-life extension of fresh fish and shellfish. Crit. Rev. Food Sci. Nutr. 36, 87-121.

Aubourg S, Gallardo J. 2005. Effect of brine on the rancidity development during the frozen storage of small pelagic fish species. Eur. Food Res. Technol. 220, 107-112.

Aubourg S, Medina I. 1999. Influence of storage time and temperature on lipid deterioration during cod (Gadus morhua) and haddock (Melanogrammus aeglefinus) frozen storage. J. Sci. Food Agric. 79, 1943-1948.

Aubourg S, Ugliano M. 2002. Effect of brine pre- treatment on lipid stability of frozen horse mackerel (Trachurus trachurus). Eur. Food Res. Technol. 215, 91-95.

Aubourg S. 2001. Fluorescence study of the prooxidant effect of free fatty acids on marine lipids. J. Sci. Food Agric. 81, 385-390.

Bligh E, Dyer W. 1959. A rapid method of total extraction and purification. Can. J. Biochem. Physiol. 37, 911-917.

Careche M, García R, Borderías J. 2002. Anchovy shelf life as affected by different chilling methods during distribution. J. Food Prot. 65, 353-361.

Chaijan M, Benjakul S, Visessanguan W, Faustman C. 2006. Changes of lipids in sardine (Sardinella gibbosa) muscle during iced storage. Food Chem. 99, 83-91.

Chapman R, McKay J. 1949. The estimation of peroxides in fats and oils by the ferric thiocyanate method. J. Amer. Oil Chem. Soc. 26, 360-363.

FAO. 2006a. Fishery statistics, capture production. In Food and Agriculture Organization of the United Nations, Yearbook 2004, Vol 98/1, p. 233, Rome, Italy.

FAO. 2006b. Fishery statistics, commodities. In Food and Agriculture Organization of the United Nations, Yearbook 2004, Vol 99, p. 176, Rome, Italy.

Harris P, Tall J. 1994. Rancidity in fish in Allen J, Hamilton R (Eds.) Rancidity in foods, 256-272. Chapman and Hall, London, UK.

Hassan I, Khallaf M, Abd-El Fattah L, Yasin N. 1999. Quality criteria period and marketing loss estimations of pre-treated and cold stored mullet fish. Grasas Aceites, 50, 208-217.

Howgate P. 2006. A review of the kinetics of degradation of inosine monophosphate in some species of fish during chilled storage. Int. J. Food Sci. Technol. 41, 341-353.

Hsieh R, Kinsella J. 1989. Oxidation of polyunsaturated fatty acids: mechanisms, products, and inhibition with emphasis on fish. Adv. Food Res. Nutr. 33, 233-341.

Huidobro A, Montero P, Tejada M, Colmenero F, Borderías J. 1990. Changes in protein function of sardines stored in ice. Z. Lebensm. Unters. Forsch. 190, 195-198.

Hwang K, Regenstein J. 1995. Hydrolysis and oxidation of mackerel (Scomber scombrus) mince lipids with $\mathrm{NaOCl}$ and $\mathrm{NaF}$ treatments. $J$. Aquat. Food Prod. Technol. 4, 19-30.

Jittinandana S, Kenney P, Slider S, Kiser R. 2002. Effect of brine concentration and brining time on quality of smoked rainbow trout fillets. J. Food Sci. 67, 2095-2099.

Kanner J, Harel S, Jaffe R. 1991. Lipid peroxidation of muscle food as affected by sodium chloride. J. Agric. Food Chem. 39, 1017-1021.

Karaçam H, Boran M. 1996. Quality changes in frozen whole and gutted anchovies during storage at $-18^{\circ} \mathrm{C}$. Int. J. Food Sci. Technol. 31, 527-531.

Losada V, Barros-Velázquez J, Gallardo J, Aubourg, S. 2004. Effect of advanced chilling methods on 
lipid damage during sardine (Sardina pilchardus) storage. Eur. J. Lipid Sci. Technol. 106, 844-850.

Lowry R, Tinsley I. 1976. Rapid colorimetric determination of free fatty acids. J. Amer. Oil Chem. Soc. 53, 470-472.

Lubis Z, Buckle K. 1990. Rancidity and lipid oxidation of dried-salted sardines. Int. J. Food Sci. Technol. 25, 295-303.

Mackie I. 1993. The effects of freezing on flesh proteins. Food Rev. Int. 9, 575-610.

Madrid A, Madrid J, Madrid R. 1994. Tecnología del pescado y productos derivados, 45-103. A. Madrid Vicente, Ediciones y Mundi-Prensa Libros, S. A., Madrid, Spain.

Martínez A, Gildberg A. 1988. Autolytic degradation of belly tissue in anchovy (Engraulis encrasicholus). Int. J. Food Sci. Technol. 23, 185-194.

Maruf F, Ledward D, Neale R, Poultier R. 1990. Chemical and nutritional quality of Indonesian dried-salted mackerel (Rastrelliger kanagurta). Int. J. Food Sci. Technol. 25, 66-77.

Medina I, Sacchi R, Aubourg S. $1994 .{ }^{13} \mathrm{C}-\mathrm{NMR}$ monitoring of FFA release after fish thermal processing. J. Amer. Oil Chem. Soc. 71, 479-482.

Olafsdóttir G, Martinsdóttir E, Oehlenschläger J, Dalgaard P, Jensen B, Undeland I, Mackie I, Henehan G, Nielsen J, Nilsen H. 1997. Methods to evaluate fish freshness in research and industry. Trends Food Sci. Technol. 8, 258-265.

Pigott G, Tucker B. 1990. Seafood: effects of technology on nutrition, 66-84. Marcel Dekker Inc., New York, USA.

Pokorný J. 1981. Browning from lipid-protein interactions. Prog. Food Nutr. Sci. 5, 421-428.

Pons-Sánchez-Cascado S, Vidal-Carou M, Nunes M, Veciana-Nigués M. 2006. Sensory analysis to assess the freshness of Mediterranean anchovies (Engraulis encrasicholus) stored in ice. Food Chem. 17, 564-569.

Rossano R, Mastrangelo L, Ungaro N, Ricio P. 2006. Influence of storage temperature and freezing time on histamine level in the European anchovy Engraulis encrasichiolus (L.,): a study by capillary electrophoresis. J. Chrom. B. 830, 161-164.

Shewfelt R. 1981. Fish muscle lipolysis. A review. J. Food Biochem. 5, 79-100.

Simopoulos, A. (1994). Fatty acids in Goldberg I (Ed.) Functional foods, designer foods, pharmafoods, nutraceuticals, 355-392. Chapman and Hall, New York, USA.
Slabyj B, True R. 1978. Effect of preprocess holding on the quality of canned Maine sardines. J. Food Sci. 43, 1172-1176.

Smith J, Hardy R, McDonald I, Templeton J. 1980. The storage of herring (Clupea harengus) in ice, refrigerated sea water and at ambient temperature. Chemical and sensory assessment. J. Sci. Food Agric. 31, 375-385.

Statsoft. 1994. Statistica for Macintosh. Statsoft and its licensers, Tulsa, Oklahoma, USA.

Takiguchi A. 1989. Effect of $\mathrm{NaCl}$ on the oxidation and hydrolysis of lipids in salted sardine fillets during storage. Nippon Suisan Gakk. 55, 16491654.

Thorarinsdóttir K, Arason S, Geirsdóttir M, Bogason S, Kristbergsson K. 2002. Changes in myofibrillar proteins during processing of salted cod (Gadus morhua) as determined by electrophoresis and differential scanning calorimetry. Food Chem. 77, 377-385.

Toledo-Flores L, Zall R. 1992. Methods for extending the storage life of fresh tropical fish in Flick G, Martin R (Eds.) Advances in seafood biochemistry. Composition and quality, 233-243. Technomic Publishing Company, Lancaster, Pa, USA.

Undeland I, Hall G, Lingnert H. 1999. Lipid oxidation in fillets of herring (Clupea harengus) during ice storage. J. Agric. Food Chem. 47, 524-532.

Visciano P, Campana G, Annunziata L, Vergara A, laneri A. 2007. Effect of storage temperature on histanmine formation in Sardina pilchardus and Engraulis encrasicolus after catch. J. Food Biochem. 31, 577-588.

Vyncke W. 1970. Direct determination of the thiobarbituric acid value in trichloracetic acid extracts of fish as a measure of oxidative rancidity. Fette Seifen Anstrichm. 72, 10841087.

Whittle K, Hardy R, Hobbs G. 1990. Chilled fish and fishery products in Gormley $\mathrm{T}$ (Ed.) Chilled foods. The state of the art, 87-116. Elsevier Applied Science, New York, USA.

Yoshida H, Kondo I. Kajimoto G. 1992. Participation of free fatty acids in the oxidation of purified soybean oil during microwave heating. J. Amer. Oil Chem. Soc. 69, 11361140. 